\title{
Historiese oorsig oor die aktiwiteite van die Afdelings binne die Fakulteit Natuurwetenskap en Tegniek
}

\section{Redaksionele opmerking}

Veel meer gegewens as wat hier verstrek word, is deur die medewerkers beskikbaar gestel. Weens gebrek aan ruimte moes die bydraes ingekort word. Die volledige artikels word egter in die Akademie-argief bewaar.

\section{Afdeling Biologie}

Op 'n Fakulteitsraadsvergadering (NW) gehou op 29 Oktober 1958 is ' $n$ kommissie bestaande uit proff. A.P. Goossens (sameroper), P.J. Botha en F.C. Eloff benoem om die wenslikheid te ondersoek of daar tot die stigting van 'n Biologie-afdeling oorgegaan moet word. Op die Fakulteitsraadvergadering van 9 Oktober 1959 rapporteer die kommissie dat daar 12 gewone lede en 16 assessorlede is wat ingeskakel kan word by so 'n nuwe afdeling. Aangesien hierdie 28 lede hulle almal ten gunste van 'n eie afdeling uitgespreek het, besluit die Fakulteitsraad op daardie vergadering om ' $n$ Afdeling Biologie in die lewe te roep. Aangesien die aanvanklike 28 lede wydverspreid oor die land gewoon het, is die Fakulteitsraad versoek om die eerste bestuur te benoem. Hierdie benoemde bestuur het bestaan uit prof. A.P. Goossen (Voorsitter), dr. R.J. Ortlepp (Ondervoorsitter), proff. G.T.S. Eiselen, F.C. Eloff en P.J. Botha. Die Akademiesekretaris het aanvanklik die Sekretariaat behartig ten einde die Afdeling te organiseer en te help met die uitbouing van die ledetal. Dat hierdie eerste Bestuur geen gras onder sy voete laat groei het nie, blyk uit die feit dat daar aan die einde van daardie Akademiejaar (Maart 1960) berig kon word dat 'n ,, hele paar" nuwe assessorlede verkies is om die geledere van die Afdeling te versterk. Uit die eerste jaarverslag blyk dit ook dat die Bestuur hulle onder andere reeds besig gehou het met aangeleenthede soos:

- Vakwoordelyste - die opstel van lyste van Plantkunde- en Dierkundeterme

- samewerking met die Vaktaalkommissie

- 'n ondersoek insake die onderrig van natuurwetenskappe op skoolvlak

- die daarstel van 'n register van wetenskaplikes en tegnoloë

Die slotparagraaf van die eerste jaarverslag lui ook dat die Bestuur alles in sy vermoë sal doen om die Afdeling Biologie uit te bou tot ,'n krag binne die Akademie".

Die ledetal van die Afdeling het inderdaad konstant toegeneem vanaf die aanvanklike 28 lede van 1959. Die jaarverslag gedateer 31 Maart 1963 het gerapporteer dat die Afdeling reeds ui 56 lede bestaan en aan die einde van die 1982-83 boekjaar is ' $n$ ledetal van 134 gerapporteer wat bestaan het uit 27 volle lede, 99 assessorlede en 8 rustende lede.
Betreffende projekte en werkprogramme is daar gedurende die eerste jare na stigting van die Afdeling gewerk op die beginsel dat takke in die verskillende sentra gestig moet word en dat die takke hulle moet besig hou met eie werkprogramme. Sentrale besprekingstemas is deur die Afdelingsbestuur aan takke voorgelê met die versoek om hulle beplanning rondom sodanige temas te doen. Gedurende die boekjaar 1961-62 is „Natuurbewaring" byvoorbeeld as besprekingstema voorgestel.

Die eerste tak is gedurende 1961 in Pretoria gestig terwyl 'n tweede tak gedurende 1963 te Stellenbosch gestig is. Lede van die Afdeling wat in kleiner sentra gesetel was, het verkies om by die aktiwiteite van hul plaaslike Werkgemeenskappe in te skakel. Die tak te Stellenbosch is steeds aktief, en oor hul aktiwiteite word gereeld in die jaarverslae van die Akademie berig. Die Pretoria-tak het gedurende 1968 ontbind.

Op 'n bestuursvergadering wat op 6 September 1963 gehou is, is besluit dat die Afdeling jaarliks ' $n$ kongres sal hou wat met die Akademie-jaarkongresse sal saamval. Die eerste Jaarkongres van die Afdeling het op 24 en 25 Junie 1964 te Pretoria plaasgevind. Tydens hierdie kongres is 8 navorsingsreferate voorgedra. Na afloop van hier die kongres is die volgende mosie eenparig deur die Jaarvergadering aanvaar: „Die Afdeling Biologie betuig graag sy groot waardering vir die nuwe reëling dat navorsingsreferate op die Jaarvergadering voorgedra word en spreek die hoop uit dat dit in die toekoms voortgesit sal word"'.

Hierdie reeling is inderdaad sedertdien gehandhaaf, met uitsondering van die jaar 1970 toe daar as gevolg van tydsoorvleueling met die aktiwiteite van die $S_{2} A_{3}$ geen kongres gehou is nie. In die lig hiervan het die Bestuur in 1970 besluit dat die Afdeling se kongres as ' $n$ jaarlikse instelling moet voortgaan, en 'n kommissie is aangewys om met ander vakorganisasies oorleg te pleeg ten einde 'n herhaling te voorkom.

Dat die Jaarkongres sedertdien van krag tot krag gegaan en goeie ondersteuning van Akademielede sowel as van jong bioloë geniet het, blyk uit die feit dat daar die afgelope 10 jaar jaarliks meer as 20 navorsingsvoordragte by die geleentheid gelewer word. Twee uitsonderlike goeie jare was 1975 en 1983 toe onderskeidelik 34 en 33 voordragte gelewer is. Hierdie jaarlikse Biologiekongres bied dus die geleentheid 
aan Afrikaanssprekende bioloë om op gereelde basis te ontmoet, na navorsingsvoordragte te luister en gedagtes te wissel.

Die Bestuur van 1973 was van oordeel dat hierdie byeenkomste ook die geleentheid bied waartydens onderwerpe wat vir die Suid-Afrikaanse bioloog van aktuele belang is, bespreek kan word. Hulle neem derhalwe die besluit om vanaf die 1974-kongres besprekingsaande te reël waartydens sodanige onderwerpe deur kundige inleiers toegelig sal word voordat die onderwerp vir bespreking oopgestel word. Hierdie besluit is sedert 1974 gereeld uitgevoer en het tot 'n groot mate bygedra om van die kongresse 'n nog groter sukses te maak. Onderwerpe waaroor daar sedert 1974 besin is, is byvoorbeeld:

1975 - Die evolusie van die mens

1979 - Word natuurbewaring oordryf?
1983 - Rekenaarondersteunde onderrig in die Biologie.

In die lig van die driekwarteeufeesviering van die Akademie is daar besluit om die 1984-besprekingstema te laat handel oor die verlede, hede en veral toekomsperspektiewe van die biologie in Suid-Afrika.

As deel van sy toekomstaak sal die Afdeling Biologie steeds streef om uitvoering te gee aan aspekte soos:

- die bekendstelling van biologie as beroepsrigting aan potensiële jong wetenskaplikes

- die uitbouing van die Afrikaanse vaktaal

- die skep van geleenthede vir veral jong bioloë om oor hul navorsingswerk te rapporteer

- die daarstelling van 'n gemeenskaplike forum vir die Afrikaanssprekende bioloog.

\section{Afdeling Chemie}

\section{INLEIDING}

Die Afdeling Chemie is op 1 Maart 1943 tydens 'n kongres by die Universiteit van Pretoria gestig. Die stigting is voorafgegaan deur ' $n$ ondersoek deur ' $n$ Skeikundige Subkomitee van die Fakulteit van Natuurwetenskap en Tegniek van die Akademie onder leiding van dr. T.J.W. Jorden. Hierdie Subkomitee het op ' $n$ vergadering op 15 September 1941 die belangrikheid van ,,die opstelling en vaslegging van 'n Afrikaanse vakterminologie op skeikundige gebied" as prioriteit gesien, en op grond van sy aanbevelings het die Afdeling tot stand gekom.

Die eerste bestuur van die Afdeling het soos volg daar uitgesien: prof. H.L. de Waal (Voorsitter), dr. A.J. Petrick (Ondervoorsitter), dr. F.E. Malherbe (Sekretaris-penningmeester), dr. T.J.W. Jorden, dr. W.G. Leemann, prof. C. van der Merwe, dr. P.F.. Rousseau, prof. P. Groenewald en dr. G.W.B. van der Lingen.

Alhoewel daar tot dusver na die ,Afdeling Chemie" verwys is, is die Afdeling amptelik deur die Akademie as die „,Afdeling Skeikunde" goedgekeur. Op 'n bestuursvergadering op 5 Mei 1960 is daar besluit om by die Akademieraad aan te beveel dat die naam Afdeling Skeikunde na Afdeling Chemie verander word. Hierdie naamsverandering is deur die Akademieraad goedgekeur.

Die Afdeling se eeste amptelike verslag wat in Akademie-dokumente opgeneem is, dek die tydperk 1945-1946. Die ledetal was toe 58, waarvan 11 lede en 47 ,,medewerkers van die Fakulteit" was. Onder die werksaamhede wat op daardie stadium spesiale aandag geniet het, was die spelling van chemie-vakwoorde en die opstel van 'n chemiewoordelys.

'n Nuwe Tak Vaaldriehoek wat die gebied Sasolburg/Vereeniging/Vanderbijlpark bedien is in die tydperk 1956/57 gestig.
Die lede van die Afdeling word ingedeel in die Tak Transvaal (wat meer as $70 \%$ van die lede het van wie die meeste in Pretoria woon), Tak Vaaldriehoek en „Buite Takverband". Die Afdeling het net een bestuur wat hierdie drie groepe gesamentlik verteenwoordig. Lede van die Tak Vaaldriehoek en van , Buite Takverband" skakel in 'n groot mate by hulle werkgemeenskappe in wat Akademie-aktiwiteite betref.

\section{LEDE VAN DIE AFDELING}

Volgens die eerste amptelike verslag van die Afdeling was daar in 1945/46 58 lede. Deur die jare het daar 'n geleidelike groei in getalle plaasgevind en op 31 Maart 1983 was die lidmaatskap 118. Hiervan was 33 volle lede, 80 assessorlede en 5 rustende lede.

\section{BYEENKOMSTE}

Sedert sy stigting hou die Afdeling gereeld jaarvergaderings, algemene vergaderings en simposia. Dit het al gebruik geword om op dieselfde dag van die jaarvergadering ' $n$ simposium of 'n algemene vergadering te reel, gevolg deur 'n dinee waarheen 'n gasspreker genooi word.

Daar word dikwels op ' $n$ tema vir die jaarprogram besluit, en in so 'n geval word alle vergaderings (gedurende die jaar en ook dié wat met die jaarvergadering saamval) dan binne die raamwerk van die tema gehou. Voorbeelde van sulke temas wat van krag was, is: water, steenkool, minerale hulpbronne, opleiding en benutting van chemici, atoomkrag, chemurgie, chemie in die geneeskunde, geochemie, petrochemie, polimeerkunsstowwe, ens.

Wat simposia betref wat nie noodwendig aan 'n jaartema gekoppel is nie, word daar op 'n aktuele onderwerp besluit en ' $n$ middag- of dagsimposium gereël. Voorbeelde van temas van simposia wat 
gehou is, is: hoogtepunte in die ontwikkeling van moderne analitiese tegnieke; chemici in die nywerheid; die wetenskap en ons regstelsel; steenkool as energiebron; die bydrae van die chemici tot die mens en sy beperkte hulpbronne; opleiding van chemici quo vadis?; outomatisasie in analitiese tegnieke; outomatisasie in die nywerheid; die tegnologie van die toepassing van kernstraling in die volksgesondheid; kunsstowwe; vloeibare brandstowwe as energiebron; geurstowwe in die parfuumbedryf; die rol van chemie in die wynbedryf; die rol van chemie in die voorbereiding van oorlogsvoering; die wonderwêreld van chemie (vir skoliere); die keramiekbedryf; ens.

'n Onderwerp wat deur die jare dikwels aandag geniet het, is die opleiding en benutting van chemici, veral in die lig van die groot tekort aan mannekrag in hierdie vakgebied.

Gedurende die afgelope twee jaar het die bestuur ook uiters geslaagde simposia oor Die wonderwêreld van chemie gereël, om daarmee 'n groter ,,chemiese bewustheid" by skoliere te kweek. By elke geleentheid was daar ongeveer 400 hoerskoolkinders wat na onderwerpe soos die chemie van brandstowwe, polimeertegnologie, chemie van staalvervaardiging, chemie as ' $n$ beroep, misdaad en chemie, ens. geluister het.

\section{VERSKYNING VAN AFRIKAANSE WOORDE- LYSTE EN WOORDEBOEKE VIR CHEMIE}

In die lig van die oogmerke van die Akademie het die Afdeling sedert sy ontstaan hom beywer vir die ontwikkeling van Afrikaanse woordelyste en woordeboeke vir chemie. Reeds tydens ' $n$ vergadering op 15 September 1941, toe die stigting van die Afdeling nog beplan is, het ,,die opstelling en vaslegging van 'n Afrikaanse vakterminologie op skeikundige gebied" prioriteit geniet.

Die eerste uitgawe van die Lys Skeikundige Terme, in getikte en afgerolde vorm het in 1951 verskyn. Die oplaag was weliswaar nie groot nie maar die lys het 9000 terme bevat. Dit is allerwee verwelkom en is binne twee jaar uitverkoop. Die ontstaan van hierdie woordelys was veral te danke aan prof. H.L. de Waal wat die leiding op hom geneem het, bygestaan deur die Chemiese Woordelyskomitee.

Die tweede hersiene uitgawe het in 1955 verskyn en is in keurige band gedrak. Die terme is tot ongeveer 13000 uitgebrei en die oplaag van 1000 is na ongeveer 8 jaar uitverkoop.

In die lig van die snel groeiende chemietegnologie en die nuwe chemieterme wat steeds by bestaandes gevoeg word, moel woordelyste gereeld hersien word om met die vordering tred te hou. As gevolg hiervan het ' $n$ komitee in 1962 die taak aangepak om 'n derde hersiene uitgawe van die woordelys uit te gee. In 1968 het hierdie taak 'n werklikheid geword met die publikasie van die tweetalige Chemiewoordeboek onder leiding van prof. H.L. de Waal.

Die woordeboek bevat 15000 woorde en is vir beide Afrikaans- en Engelssprekendes van groot waarde omdat die Engels-Afrikaans ook na die Afrikaans-Engels omgeskakel is.
Die hersiening van die Chemiewoordeboek gaan egter onverpoos voort onder leiding van dr. D.F. Louw van Inligtings- en Navorsingsdienste, WNNR, wat as projekleier optree. 'n Redelik uitgebreide kartoteek met sowat 15000 aanvul!ende terme is reeds opgebou en Afrikaanse ekwivalente vir die Engelse terme word gesoek en/of saamgestel.

\section{VERSKYNING VAN AFRIKAANSE HANDBOEKE IN CHEMIE}

In 'n wetenskaplike ondersoek wat in 1975 deur die Akademie gedoen is na die posisie van Afrikaanse handboeke aan Afrikaanse universiteite, is daar bevind dat daar ' $n$ groot behoefte in hierdie verband is, veral in die natuurwetenskappe en op eerstejaarsvlak.

Op inisiatief van die Afdeling Chemie is aandag gegee aan die daarstelling van Chemiehandboeke. Die oorkoepelende paneel wat vir hierdie hele aksie verantwoordelik was, was prof. R.R. Arndt (Voorsitter); prof. C.J.H. Schutte (Ondervoorsitter); prof. J.G. Leipoldt (sameroeper van die werkgroep vir analitiewe chemie); prof. J.J. Cruywagen (sameroeper van die werkgroep vir fisiese en anorganiese chemie); prof. C.W. Holzapfel (sameroeper van die werkgroep vir organiese chemie); prof. R.G. Böhmer, prof. L.D.C. Bok; dr. H.D. Nelson en dr. D.J.J. van Rensburg.

Die saak het momentum gekry en op 10 April 1981 is ' $n$ lang gekoesterde ideaal verwesenlik met die verskyning van die eerste Afrikaanse handboek in chemie, naamlik Inleiding tot die Anorganiese en Fisiese Chemie. Die paneellede wat verantwoordelik was vir die skryf van hierdie handboek is J.J. Cruywagen, J.B.B. Heyns, H.G. Raubenheimer en P.C. van Berge (in medewerking met L.D.C. Bok, E.L.J. Breet, K. de Clerk, H.D. Nelson, C. Olivier, C.L. Sander en J.A. van den Berg).

In 1982 het 'n verdere twee Afrikaanse handboeke vir chemie verskyn. Die eerste is Inleiding tot die Organiese Chemie met outeurs B.V. Burger, C.W. Holzapfel, D.F. Schneider en H.F. Strauss. Die tweede is Inleiding tot die Analitiese Chemie deur J.G. Leipoldt, S.S. Basson, H.D. Nelson en W.P. Pelser (met medewerking van R.G. Böhmer, C.J. Liebenberg, C. Olivier en D.J.J. van Rensburg).

Die handboeke is vir die student geskryf om hom of haar te help om basiese chemiese beginsels te verstaan en tegelykertyd 'n aansienlike hoeveelheid beskrywende chemie te bemeester.

Met die verskyning van hierdie handboeke is daar 'n daadwerklike bydrae tot die uitbouing van die Afrikaanse taal en die bevordering van die wetenskap gelewer.

\section{ANDER AKTIWITEITE}

Behalwe die reeds genoemde inisiatief en betrokkenheid by vergaderings, simposia, woordeboeke en -lyste, en handboeke, was of is die Afdeling by ander aksies betrokke, waar onder die volgende:

- In 1965 het die Afdeling Chemie 'n publikasie Water die lig laat sien. Dit het uit die geledere van 
die Afdeling ontstaan en onder leiding van dr. G.J. Stander het 'n span natuurwetenskaplikes hierdie omvattende werk saamgestel.

- Ten einde die aktiwiteite van die Afdeling in sentra ander dan Pretoria te stimuleer, reël die Bestuur van tyd tot tyd (in samewerking met lede van die betrokke sentra) byeenkomste aldaar. Sulke byeenkomste het al in Potchefstroom, Johannesburg, Stellenbosch, Secunda, Sasolburg en Bloemfontein plaasgevind.

- Die Afdeling het 'n studiestuk in verband met die wetenskapbeleid van die Republiek opgestel en was in 'n komitee verteenwoordig wat die aangeleentheid ondersoek het met die oog op die samestelling van die amptelike dokument in hierdie verband.

- Die Afdeling was ook betrokke by 'n komitee wat die gesproke oordrag van getalle in Afrikaans ondersoek het.

- Daar is ook skakeling en samewerking met ander vakverenigings soos bv. die Suid-Afrikaanse Chemiese Instituut, en die Afdeling word ook op die nasionale komitee vir die Internasionale Unie vir Suiwer en Toegepaste Chemie (IUPAC) verteenwoordig.

- Daar word ook daadwerlike aksies geloods om bydraes vir die SA Tydskrif vir Natuurwetenskap en Tegnologie te kry.

\section{Afdeling Geneeskunde}

Die Afdeling Geneeskunde het die afgelope kwarteeu van 'n beskeie ledetal van 180 tot 208 gegroei, soos die jongste sensus getoon het. Waar die Afdeling aanvanklik slegs uit die een tak nl. Noord-Transvaal bestaan het, is daar tans drie takke $\mathrm{nl}$. die Gedenktak Christo Beyers (Johannesburg), die Tak Eugène Nielen Marais (Pretoria) en die Tak Simon van der Stel (Stellenbosch en Kaapstad). Alhoewel daar wel stigtersvergaderings gehou is in Natal en in Bloemfontein, funksioneer lede in hierdie gebiede tans buite takverband.

'n Terugblik oor die jaarverslae aan die einde van die 50 bestaansjare van die Akademie bring interessante grepe na vore, bv. uit die 1947/48-jaarverslag van die Fakulteit Natuurwetenskap en Tegniek: ,Die Geneeskunde-Afdeling met sy setel in Germiston en waarvan die administrasie deur dr. J.H. Rauch, Posbus 145, Germiston, waargeneem word. Die bestuur van die afdeling is soos volg:

Dr. C.F. v.d. Merwe (Voorsitter)

Dr. H.O. Mönnig (Ondervoorsitter)

Dr. J.H. Rauch (Sekretaris)

Prof. dr. L.J. te Groen

Dr. I.P. Schabort

Dr. C.F. Krige

Prof. dr. P.J. du Toit

Dr. J.G.M. Richter

Die Afdeling het een tak nl. die Noord-Transvaalse

\section{AKADEMIEPRYSE WAARVOOR LEDE GEKWALIFISEER HET \\ Havengaprys}

Sedert die Havengaprys in 1947 ingestel is, het die volgende persone dit vir die vakgebied Chemie ontvang: dr. A.I. Malan (1948); prof. H.L. de Waal (1951); dr. F.J. de Villiers en dr. T.J.W. Jorden (1955); dr. A.J. Petrick (1958); prof. G.W. Perold (1962); dr. P.R. Enslin (1965); prof. D.G. Roux (1968); prof. V. Pretorius (1971); prof. C.J.H. Schutte (1974); prof. C.F. Garbers (1977); dr. F.J. Joubert (1981); en prof. C.W. Holzapfel (1983).

\section{M.T. Steyn-prys vir Natuurwetenskaplike en Tegniese Prestasie}

Die volgende chemici het dit reeds ontvang: dr. P.E. Rousseau (1973), dr. C. v.d. Merwe Brink (1981) en dr. G.J. Stander (1983).

\section{Erepenning vir Wetenskaplike Vakbevordering}

Die Erepenning is in 1980 deur dr. D.J.J. van Rensburg verower.

\section{Erepenning vir Natuurwetenskaplike Prestasie (1956- 1971) \\ Dr. G.J. Stander het die erepenning in 1971 ont- vang.}

tak. Die stigting van 'n tak op die Witwatersrand het vorm geneem met die inskakeling van die Christo Beyers Mediese Gedenkvereniging (Maart/April vanjaar). Die totale ledetal van die Afdeling staan tans op 111, waarvan 20 volle lede en 91 assessorlede van die Akademie is".

Ten spyte van relatief onaktiewe fases in al drie die takke was daar die afgelope dekade doelgerigte vordering en 'n duidelike oplewing in alle sfere soos bewys word deur die talle vergaderings en simposia, verskeie bekronings en die individuele prestasies van lede van elke tak.

Die Havengaprys vir Geneeskunde is reeds aan 8 lede toegeken nl. prof. M.W. Henning (1961), prof. O.S. Heyns (1964), prof. A.J. Brink (1967), dr. H.P. Wassermann (1970), prof. J.H. Louw (1973), prof. H.W. Snyman (1977), prof. B.J. Meyer (1979) en prof. P.J. Pretorius (1982).

In 1970 ontvang dr. J.H.S. Gear ook die Erepenning vir Natuurwetenskaplike Prestasie van die Akddemie, en in 1975 ontvang prof. B.C. Jansen die Havengaprys vir landbou. Die talle ander individuele prestasies en bekronings sal onder die aktiwiteite van elke tak saamgevat word.

\section{GEIDENTAK CHRISTO BEYERS}

,Die stigting van die Gedenktak Christo Beyers in die jaar 1939 was 'n mylpaal in die geskiedenis van 
die Afrikaanse geneesheer in Johannesburg en op die Rand. Met die stigting van hierdie Mediese Vereniging is 'n groep geneeshere bymekaar getrek wat 'n gemeenskaplike strewe en doel voor oë gehad het die handhaaf en uitbou van hulle taal en kultuur in 'n volksvreemde en vyandiggesinde stad".'

Die gedagte om 'n Afrikaanse Mediese Vereniging op die Rand te stig het ontstaan by dr. C.F. Krige tydens 'n gebruiklike Dinsdagmiddagete waar ses Afrikaanse spesialiste gereeld vergader het. Op hierdie tydstip is daar reeds voorgestel om 'n oudkollega, dr. Christiaan Frederick Beyers, op hierdie wyse te gedenk. So is die stigtingsvergadering belê vir 7 Maart 1939, waarby die Christo Beyers Mediese Gedenkvereniging tot stand gekom het. Die naam sou later verander word na die Gedenktak Christo Beyers. Aansluiting van die gedenktak by die S.A. Akademie vir Wetenskap en Kuns is egter eers na die onverpoosde pogings van baanbrekers soos o.a. dr. C.F. Krige, dr. I.P. Schabort, dr. H.W. Snyman, dr. H.O. Mönnig en dr. L.J. te Groen tydens die jaarvergadering in 1948 bewerkstellig.

Die Gedenktak Christo Beyers wat aanvanklik gesien is as 'n eksklusiewe klub vir geneeshere met 'n beperkte ledetal van 50 , het hom sedertdien as tak van die Fakulteitsraad vir Natuurwetenskap en Tegniek by uitstek en onverpoosd beywer vir die bevordering van Afrikaans as geneeskundige vaktaal. Daarbenewens stel die gedenktak nie alleen hoë eise aan kollegas wat as lede wil kwalifiseer nie, maar veral ook aan die Christo Beyers-gedenklesing wat jaarliks gehou word. Daar is ook besluit om die toekenning van 'n erepenning aan die jaarlikse gedenklesing te koppel.'

Alhoewel die reglement reeds in Maart 1960 aan die jaarvergadering vir goedkeuring voorgelê is, het dr. Hennie Pretorius as Voorsitter namens die bestuur van die Gedenktak Christo Beyers die eerste erepenning op 23 Oktober 1965 in die Hotel Casa Mia aan dr. C.F. Krige oorhandig. Sedertdien is die erepenning toegeken aan prof. F. Daubenton, drr. Chris Jooste, Louw van Rooyen en Louis du Plessis, proff. Chris Barnard, C.J. Mieny (1971), H.W. Snyman (1972), F.G. Geldenhuys (1975), J.N. Coetzee (1976), O.W. Prozesky (1978), R.C. Franz (1982) en P.J.P. van Blerk (1983). Christo Beyers-gedenklesings is ook gelewer dear dr. G.H. Roux, prof. L.M. Jonck, prof. W.A. van Niekerk en prof. G. Falkson. Hierdie gebaar van die gedenktak en die bydraes wat daarop gevolg het, was inderdaad 'n betaamlike wyse om 'n kranige chirurg, verbecldingryke navorser, vermoende skrywer en akademikus wat deurgaans in murg en been Afrikaner gebly het, ryklik te vereer. ' $n$ Besondere bydrae ,Christo Beyers, sy lydgenote en geskrifte" deur prof. C.J. Mieny het in Maart 1974 in die SA Geneeskundige Tydskrif verskyn."

\section{TAK NOORI)-TRANSVAAI. - IATER HERBENOEM TOI TAK ELGENE NIELEN MARAIS}

Die Sekretariaat van die rak Noord-Transvaal, aanvanklik die enigste tak van die Afdeling Genees- kunde en oorspronklik gesetel op die Rand, het later na Pretoria verskuif. Tydens die 1964-jaarvergadering wat vir Woensdag, 26 Februarie in die nuwe Ginekologielesingsaal in die Kliniesegebou van die Universiteit van Pretoria belê is, is die konsepreglement van die Tak Noord-Transvaal voorgelê en aanvaar. Vier jaar later het prof. H.W. Snyman, hoof van die Departement Interne Geneeskunde en dekaan van die Fakulteit Geneeskunde, 'n motivering aan die Akademieraad voorgelê waarin bepleit word dat die tak hernoem word tot Tak Eugène Nielen Marais. Die slotparagraaf van die stuk verdien spesiale vermelding. ,,Met hierdie kort skets van Eugène Nielen Marais se Afrikaansheid, sy skeppende bydraes tot ons taal, ons volkslewe, ons landsbiologie en ons geneeskunde, in sy heel afgespeel in en om sy geboorteplek, Pretoria, stel ek voor dat dit gepas sou wees dat die naam van hierdie groot landseun, wetenskaplike en kultuurmens voortaan as eienaam van die huidige Noord-Transvaalse tak van die Afdeling Geneeskunde gebruik word". Die jaar 1968 was vir hierdie tak dus 'n geskiedkundige jaar omdat die Akademieraad die versoek van die tak goedgekeur het op aanbeveling van en na deeglike navorsing en besinning deur 'n subkomitee bestaande uit proff. H.W. Snyman en B.C. Jansen. Tans bestaan die tak uit 22 volle lede en 58 assessorlede. Vergaderings word gereeld gehou en 'n uiteenlopende spektrum van voordragte word aangebied. Onderwerpe wissel van ,,Lugvaartgeneeskunde" tot „Die Boesman, sy wetenskap en kuns". Dit dien vermeld te word dat deur referate van 'n nie-geneeskundige aard oor onderwerpe soos kunswaardering, beleggingsmoontlikhede, universiteitsdidaktiek, ens. aan te bied, daar 'n duidelike oplewing in die bywoning van vergaderings was. Die lewendige ondersteuning vanuit ander geledere in die Pretoriase werksgemeenskap, sowel as deur lede van die Christo Beyers-gedenktak, was besonder bemoedigend. Die eerste Eugène Marais-gedenklesing is in 1979 ingestel en deur professor H.W. Snyman voorgedra. Eers 4 jaar later, nadat die gedenklesing deur die nuwe bestuur aan 'n erepenning gekoppel is, is die tweede gedenklesing deur professor C.J. Mieny aangebied nl. ,Eugène Nielen Marais, feit en fabel”. Die eerste twee erepennings is by die Voortrekkermonument-restourant tydens die dinee wat op die 1983-jaarvergadering van die Afdeling Geneeskunde gevolg het, aan die twee referente oorhandig. Die Eugene Marais-gedenkpenning is goedgunstiglik deur dr. Robert Bauling van Ethno (Edms.) Bpk. geborg. Vanwee sy diepgaande kennis van C.L. Leipoldt is prof. C.J. Mieny genader om verskeie voordragte oor die volksdigter te lewer. Tydens die 7 de vyfjaarlikse landswye skrywerskongres en Leipoldtfees wat op 19 en 20 September 1980 in Stellenbosch gehou is, het sy voordrag ,,Leipoldt, die veelsydige" besondere byval gevind. Tydens 'n Leipoldt-huldigingsfunksie gereel deur die Christo Beyers-tak is hulde gebring aan sy boek Leipoldt in Londen, die vormingsjare. ' $n$ Soortgelyke funksie is ook gereel deur die Geneeskundige Historiese Vereniging in die Musaion op 18 April 1980. ,C. Louis Leipoldt en Joseph Pulitzer, 
'n ontmoeting tussen eksentrieke begaafdes'" verskyn in dieselfde jaar in die Leipoldt-gedenkuitgawe van die vereniging. Tydens die jaarvergadering op $22 \mathrm{Mei}$ 1983 het die Tak Eugène Nielen Marais die vierde eksemplaar van die werk Leipoldt in Londen aan die voorsitter van die Akademie oorhandig. Verskeie ander hoogtepunte dien vermelding. Die mylpaal in die geskiedenis van die tak is die verskyning van die eerste Afrikaanse Geneeskundige Woordeboek soos saamgestel deur professor H.W. Snyman (1972). So is ' $n$ opdrag wat sy oorsprong in die laat vyftigerjare in die vorm van 'n woordelys gehad het, as 'n reuse taak volbring. 'n Hersiende lys van aptekersterme het reeds in 1960/61 verskyn. Insgelyks het die tydskrif Geneeskunde vanweë die versiendheid en deursettingsvermoë van professor H.W. Snyman ook in 1959 verskyn.

Boeke deur lede van die tak gepubliseer:

Meer as ' $n$ dagtaak. Botha, H.P.

Die huisarts: 'n Suid-Afrikaanse siektegids. Botha, H.P.

Handleiding in die Chirurgie. Dreyer, B.J.v.R., Franz, R.C., Barnard, P.M., De Villiers, J.C., Louw, J.H., Cilliers, P.H.K., Grotepass, F.W., Nel, C.J.C., Malherbe, W.D.F., Van Zijl, J.A., De Kock M., De Villiers, R.

Kort ginekologiese handboek. Geldenhuys, F.G. \& Bremer, P.M.

Elementêre Mediese Biofisika. Járos en Meyer.

Praktiese Menslike Mikro-anatomie. Knobel, D.P.

Ginekologie en Obstetrie. Knobel, J.

Fisiologiese Basis van Geneeskunde (Reeds 3 uitgawes). Meyer, B.J.

Leipoldt in Londen. Mieny, C.J.

Kindersiektes. Pretorius, P.J.

Babavoeding. Pretorius, P.J.

Infant Feeding and Nutrition (vertaling). Pretorius,

P.J.

Alledaagse kindergeneeskundige probleme. Pretorius, P.J.

Ondersoek oor die invloed van voedings met verskillende samestellings op die genesing van $k$ wasjiorkor. Pretorius, P.J.

Sestig blare in my hand. Snyman, H.W.

Geneeskundige Woordeboek Eng./Afr. Snyman, H.W.

Geneeskundige Woordeboek Afr./Eng. Snyman, H.W.

Die Ultrastruktuur van die Sel. Theron, J.J.

\section{TAK SIMON VAN DER STEL}

Hierdie besonder aktiewe tak het sy stigtingsvergadering op 24 Julie 1956 te Kaapstad gehou. Die eerste bestuur is soos volg saamgestel:

Voorsitter: prof. A.J. Brink

Sekretaris: dr. J.W. de Klerk

Addisionele lid: dr. P.L. Tredoux.

Sedert die stigtingsvergadering is daar 80 vergaderings gehou. Tans bestaan die ledetal uit 11 volle lede, 32 assessorlede en 4 rustende lede.
Boeke deur lede van die tak gepubliseer:

Hart-en longsiektes. Brink, A.J. en De Kock, M.A. (1972).

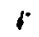

Die hart en sy siektes (Nasou). Brink, A.J. (1980).

Jou Hart en Lewe (Femina Uitgewers). Brink, A.J. (1982).

Woordeboek van Afrikaanse Geneeskundeterme. Brink, A.J. en medewerkers (1979). Eerste verklarende woordeboek in Afrikaans na 'n Taalkomitee sedert 1958 daaraan gewerk het.

'n Handleiding in die Chirurgie. Dreyer, B.J.v.R. en medewerkers (1980).

Die Pasgebore baba (Juta). Keet, M.P., Shore, S.C., Harrison V.C. (1960).

Die Pasgebore baba (2de uitgawe, Juta). Keet, M.P., Shore, S.C., Harrison, V.C. (1978).

Interne Geneeskunde vir Verpleegsters. Wassermann, H.P. (1972).

Inleiding tot Interne Geneeskunde (4de uitgawe). Wassermann, H.P. (1973).

Kliniese Fisiologie van Sykamerondersoeke (1ste uitgawe). Wassermann, H.P. (1974).

\section{BLOEMFONTEIN}

Verskeie Akademielede het reuse bydraes gelewer tot die totstandkoming van die Fakulteit van Geneeskunde aan die Universiteit van die Oranje-Vrystaat. Etlikes staan nog sterk in die tuig. Die stigting van die Tak Emily Hobhouse tydens die 1984-jaarvergadering word in die vooruitsig gestel.

\section{SLOTOPMERKING}

Die bestuur van die Afdeling Geneeskunde wil graag van hierdie geleentheid gebruik maak om dank te betuig en om hulde te bring aan taklede sowel as Akademielede buite takverband wat ons gemeenskaplike strewe en doel verder uitgebou het - nl. handhawing van die Afrikaanse taal en kultuur in ons akademiese en professionele doen en late. Die bekronings op nasionale vlak en veral dié ver buite ons landsgrense, vul ons met trots. Mag dit van krag tot krag gaan.

\section{VERWYSINGS}

1. Cieyser, O., Nöthling, F.J. en die Bestuur van Ciedenktak Christo Beyers. Gedenkıak Christo Beyers: Historiese Oorsig 1939-1969.

2. Mieny, C.J. (1974). Christo Beyers, sy tydgenote en geskrifte. S. Afr. Med. J. 48(1), 468-471. 


\section{Afdeling Ingenieurswese}

Die Afdeling Ingenieurswese van die Suid-Afrikaanse Akademie vir Wetenskap en Kuns was een van die eerste afdelings wat gevorm is nadat die Fakulteit Natuurwetenskap en Tegniek in Mei 1941 gestig is. Trouens, die ingenieurs het 'n noemenswaardige aandeel gehad in die stigting van bogenoemde fakulteit en was dus ook sterk verteenwoordig in die eerste bestuur van die fakulteit, wat by die stigtingsvergadering gekies is en waar ons name aantref soos diè van drr. J.K. Marais, R.L. Straszacker, C.V. von Abo, A.J.A. Roux en W. Kupferburger (geoloog).

Met die stigting van die Afdeling in 1942 was daar 35 lede en assessorlede, en die getalle het gegroei tot 86 in 1948, 200 in 1958 en 272 in 1983. Interessant was die ontwikkeling dat die Afdeling gedurende die veertigerjare as beskermheer opgetree het vir die ingenieurstudentevereniging by die Fakulteit Ingenieurswese, Universiteit van Stellenbosch, en dat die Afdeling se groei vir die helfte van sy lewe veral te danke was aan die sterk ondersteuning van juniorlede totdat lidmaatskap in 1970 afgeskaf is. In 1948 was daar bv. 77 ondersteuners waarvan 51 in die juniortak op Stellenbosch saamgesnoer was.

Die Afdeling het reeds van die begin af 'n tuiste gebied vir die geoloë toe daar gevind is dat hul getalle nie ' $n$ aparte afdeling geregverdig het nie. Dieselfde het gegeld vir die bourekenaars wat in 1965 ook as lede van die Afdeling bygekom het.

Hierdie nie-ingenieurslede van die Afdeling was aktiewe deelnemers wat reeds waardevolle bydraes gemaak het tot ons gesamentlike taak, en hulle doen dit nog steeds.

In 1958 het die Afdeling uit vyf takke bestaan, naamlik Noord-Transvaal, Witwatersrand, OranjeVrystaat, Vaaldriehoek en die Suidelike Tak (Kaapland). Vandag is daar vier takke want die Tak Oranje-Vrystaat se getalle was te min om as 'n aparte tak te fungeer en hierdie lede saam met 'n paar ander wat wyd verspreid is, staan nou as Buite Takverband bekend.

Aangesien dit een van die hoofdoelstellings van die Akademie is om die Afrikaanse taal te bevorder, is daar heel van die begin af besef dat daar iets gedoen moet word om die gebrek aan geskikte woorde en terme in die Afrikaanse vaktaal uit die weg te ruim en dat hierdie vaktaal 'n lewende taal moet wees. Gevolglik het lede van die Afdelings met ywer deelgeneem aan die opstel van vakwoordelyste en ook die gebruik daarvan aangemoedig deur die lewering van referate. Die Afdeling Ingenieurswese het 'n groot bydrae gelewer tot die uitbou van die vaktaal deurdat sy individuele lede aangemoedig is om elkeen in sy eie spesialiteitsrigting bydraes te lewer waar dit die effektiefste gedoen kon word, gewoonlik in werkverband, maar steeds in samewerking met erkende organisasies soos die Vaktaalburo en ander aktiewe vaktaalorganisasies. Ons wil hiermee glad nie te kenne gee dat die Afdeling Ingenieurswese die eerste inisieerders was om die Afrikaanse vaktaal aan te vul en te bevorder nie. Inteendeel, die Afdeling wil baie graag hulde bring aan die stille werkers wat sedert die ontstaan van Afrikaans hulle bydrae gelewer het. So bv. het een van die eerste vaktaalwoordelyste (Spoorwegterme) alreeds in 1934 verskyn as gevolg van die aktiewe inspirasie van dr. M.M. Loubser. Hy was ook grotendeels verantwoordelik vir die invoer van suiwer tegniese Afrikaans by die S.A. Spoorweë. Dr. Loubser het hom ook saam met ander ingenieurs, wat net so sterk oor die bevordering van die Afrikaanse vaktaal gevoel het, beywer vir die stigting van die Fakulteit Natuurwetenskap en Tegniek en ook die stigting van die Afdeling Ingenieurswese, wat 'n forum geskep het vir ingenieurs, geoloë en bourekenaars van alle ouderdomme om hulself in hul moedertaal op hulle vakgebied te kon uitleef deur die lewering van referate, die organisasie van en deelname aan simposia ens., en hulle ook in staat te stel om hierdie taal op 'n geordende wyse uit te bou as erfenis vir die nageslag. Dr. Loubser se inspirasie het ook daartoe gelei dat sy twee ingenieurseuns, drr. J.G.H. Loubser en R.S. Loubser, ywerige werkers van die Afdeling geword het en groot bydraes tot die taak oor die afgelope dekades gemaak het.

Vakwoordelyste wat deur lede van hierdie Afdelings geïnspireer is, het een na die ander verskyn, en so was een van die eerstes die Ontwerpwoordelys van Staalwerkersterme wat opgestel is deur drr. P. Stoker, C.M. Kruger en T.J. Wilken-Jorden, en wat in die eerste gedrukte uitgawe van Tegnikon in Julie 1949 verskyn het. Onder die ander eerstes kan ook getel word die Tegniese Woordelys van die SAS \& H geinspireer deur dr. M.M. Loubser, wat in 1948 verskyn het, en dan ook nog die lys van Afkortings van Internasionale Eenhede onder leiding van dr. R.L. Straszacker, een van ons huidige erelede. Met die stigting van die Vaktaalburo in 1947 het hierdie buro egter die reuse taak van ordening op hierdie gebied op sy skouers geneem. In hierdie verband wil ons graag melding maak van die volgende woordelyste wat deur lede van hierdie Afdeling geïnisieer is:

(a) Die Elektrotegniese Verklarende Woordelyste

(b) Ingenieursterme

(c) Kernenergieterme

(d) Geologiese en Verwante Terme en Voorlopige Paleontologiese Woordelys

(e) Landbou-ingenieursterme

(f) Mynbouterme

(g) Watertegnologieterme

'n Hele paar van die vakwoordelyste hel gekulmineer in die daarstelling van vakwoordeboeke, en die wat in die vakgebied van hierdie Afdeling val, is die volgende:

(a) Bouwoordeboek (Engels-Afrikaans; AfrikaansEngels) op die inisiatief van Simon Faris, Dept. Boukunde, Pretoriase Tegniese kollege, en T.H. Loun.

(b) Elektrotegniese W'oordeboek (Engels-Afrikaans; 
Afrikaans-Engels) (SAS): Kulminasie van die werk wat so ver terug as die vroeë dertigerjare aan die gang gesit is op inisiatief van M.M. Loubser.

(c) Evkomwoordeboek (Engels-Afrikaans; Afrikaans-Engels): Geinisieer deur J.H. Smith en F.W. Stutterheim.

(d) Motorwoordeboek (Engels-Afrikaans; Afrikaans-Engels): Gebaseer op 'n Lys van Spoorweg- en under Tegniese Terme wat in 1939 reeds deur die S.A. Spoorweë uitgegee is.

(e) Poskantoorwoordeboek (Engels-Afrikaans; Afrikaans-Engels): 'n Uitbouing van die Voorlopige Lys Poskantoorterme wat in 1951 verskyn het en wat opgestel is deur die Poskantoor-Terminilogiekomitee met J.F. Dick as Voorsitter en D.P.J. Retief as Ondervoorsitter.

(f) Staalwoordeboek (Outeur M.W.O. Roux): Hierdie woordeboek is ' $n$ kulminasie van die voorafgaande werk wat by YSKOR gedoen is soos reeds hierbo vermeld.

(g) Sweiswoordeboek: Opgestel deur die S.A. Spoorweë in 1970 (Outeur G.W.T. Oosthuyzen).

(h) Opmeetwoordeboek (Engels-Afrikaans; Afrikaans-Engels): 'n Kulminasie van die werk wat reeds in 1932 deur Boonzaaier begin is met ' $n$ Lys Landmetersterme en wat later deur P.C. Grobler verder afgehandel is.

Die uitdra van die geskrewe woord en verspreiding van kennis is ' $n$ vername faktor vir die bevordering van 'n volk se taal en kultuur, en daar is dus reeds vroeg in die bestaan van die Afdeling gevoel dat ' $n$ medium waarin die vaktaal goed gebruik kon word en waarin die referate wat by die verskillende byeenkomste gelewer word in druk kon verskyn, noodsaaklik is. Die Ingenieursafdeling het in April 1948 die inisiatief geneem deur met 'n tydskrif in afgerolde vorm te begin en in Julie 1949 het die tydskrif Tegnikon in samewerking met die Afdelings Wis-en Natuurkunde, en Skeikunde, die lig gesien. Die verantwoordelikheid vir die voortbestaan van Tegnikon is deur die Afdeling Ingenieurswese aanvaar, waar dit op die skouers van dr. P. Stoker en mnre. H.C.H. Hutten en P.N. Basson gerus het totdat Tegnikon in 1961 by die nuutgestigte Tydskrif vir Natuurwetenskappe ingelyf is. Die behoefte aan 'n tydskrif vir tegnologie het egter voortbestaan, en in 1965 herleef Tegnikon onder leiding van prof. F.G. Heymann totdat dit weer eens ingelyf is in Die Suid-Afrikanse Tydskrif vir Natuurwetenskap en Tegnologie wat in Maart 1982 vir die eerste maal verskyn het.

Gedurende die sestigerjare hel die groei van die Afdeling Ingenieurswese en dié van die ander afdelings in die fakulteit daartoe gelei dat oorkoepelende simposiums gereel is waarby ander afdelings van die fakulteit betrek is. Hierdeur is ' $n$ betekenisvolle bydrae gelewer tot die ontwikkeling van denkrigtings in die land. Onderwerpe wat hier met die loop van die jare aangevoor is, het ingesluit die ontwikkeling van die grensgebiede, die beter benutting van die ingenieur in die Weermag, verskeie aspekte van die beter benutting van die mensepotensiaal, gebruik van water in die land en die benutting van ingenieurstegnici. Ons dink hier bv. aan die simposia wat deur die Afdeling Ingenieurswese geinspireer is soos byvoorbeeld:

1964: Die rol van die ingenieur in die verdediging.

1969: Kernkrag in Suid-Afrika.

1974: Besproeiingsingenieurswese op die plaas.

Benewens die hou van simposia is daar ook taalkursusse oor tegniese taalgebruik in Afrikaans gehou. Hierdie kursusse is goed bygewoon en het die gewenste uitwerking gehad om die gebruik van tegniese Afrikaans in die praktyk te bevorder. Hierdie Afdeling sal ook in die toekoms verdere aandag aan hierdie aangeleentheid skenk en die hou van simposia sal ook voortgaan.

Een van die groot bydraes wat die Afdeling as sodanig kon lewer en wat in hul individuele hoedanigheid deur sy lede ondersteun is, is die bevordering van die professie van die ingenieur, asook dié van die tegnikus.

Die Afdeling het in 1949 versoek dat die Akademie vertoë rig tot die Departement van Onderwys, Kuns en Wetenskap dat ondersoek ingestel word na die wenslikheid om 'n tweede Afrikaanse fakulteit vir ingenieurswese te stig en dat dit hier in die Noorde gesetel moet wees. Eersgenoemde het aanleiding gegee tot die Olckers-verslag van 1951 oor die behoefte aan opgeleide ingenieurs in Suid-Afrika, wat bygedra het tot die stigting van die Ingenieursfakulteit aan die Universiteit van Pretoria in 1956.

Die tweede versoek het aanleiding gegee tot die aanstelling van die welbekende Straszacker-kommissie oor die opleiding van ingenieurs.

Om verder te help met opleiding deur medium van Afrikaans het daar ook reeds twee handboeke verskyn, naamlik Inleiding tot Elektronika deur L. van Biljon en J.D. van Wyk; en Elektronika deur C.J. Viljoen, en ons vertrou dat daar nog meer sal volg.

'n Verdere groot bydrae wat die Afdeling gelewer het as een van die pioniersliggame in die land, was die bevordering van die ingenieurswese tot volle professionele status.

In dieselfde trant het die Afdeling hom ook aktief beywer vir die regmatige posisie van die tegnikus en die tegnoloog in die ingenieursraamwerk, deur onder meer sy eie ondersoeke na die stand van sake te onderneem. Dit was 'n bydraende faktor tot die aanstelling van die Goode-komitee van ondersoek na ingenieurstegnici, waarop Akademielede hulle ook laat geld het. Die aanbevelings van die Goode-komitee het veel bygedra tot die bevordering van die status van die tegnikons soos ons dit nou ken.

Dit was 'n kenmerk van die optrede van die Afdeling dat sy sterkte daarin gelê het dat hy 'n gesonde forum verskaf het vir die ontwikkeling van die gedagtegang van sy lede en dat dit uitdrukking gevind het in die optrede van die enkelinge in hulle werkgebied, waar meer bereik kon word as wat die Afdeling op sy eie sou kon verrig. Soos verwag is, het sy lede in hulle werkgebiede besonder gepresteer en het hulle internasionaal erkenning verkry vir hulle vermoens. 'n Hele aantal van ons lede het ere-doktersgrade van ons 
universiteite ontvang as erkenning vir uitstaande prestasies, en dan kom dit ook heel dikwels voor dat lede van hierdie Afdeling uitgenooi word om referate op internasionale konferensies te lewer. Afgesien van buitelandse erkenning het lede van hierdie Afdeling ook mildelik gedeel in die toekenning van Akademiebekronings vir uitstaande prestasies.

Ons het ook gevalle waar daar van ons lede deur buitelandse instansies vereer is as erkenning vir buitengewone prestasies van internasionale waarde, soos die volgende paar voorbeelde illustreer:

Dr. C.M. Kruger ontvang in 1966 'n ere-doktersgraad in die Ingenieurswese van die Universiteit van Aachen, Duitsland, as erkenning vir sy grool verdienste ten opsigte van die tegniese ontwikkeling van die metallurgiese vervaardigingsprosesse in die ysteren staalwerke en die uitbreiding van die aanwendingsgebiede vir yster en staal.

Die republiek van China het dr. A.J.A. Roux vereer met die toekenning van die Grand Cordon of the Order of the Brilliant Star as erkenning vir sy bydrae gelewer op internasionale vlak ter bevordering van kernenergie.

Dr. J.G.H. Loubser ontvang erkenning van die International Railway Journal vir sy besigheidsgeorienteerde bestuursfilosofie wat 'n nuwe wêreldbeeld vir die S.A. Spoorweë geskep het.

Prof. J.D. van Wyk, prof. P.L. Swart, mnr. D.N.

\section{Afdeling Landbouwetenskappe}

\section{ONTSTAAN VAN DIE AFDELING \\ LANDBOUWETENSKAPPE.}

Gedurende die periode 1944/45 het die gedagte by landboukundiges van die Fakulteit Natuurwetenskap en Tegniek ontstaan om 'n selfstandige Landbouafdeling in die lewe te roep. 'n ,Organiserende Komitee van Landbou" het die aanvoorwerk gedoen en aanbevelings aan die Fakulteitsraad genaak.

Die stigtingsvergadering is op 1 Mei 1945 in die Senaatskamer van die Universiteit van Pretoria gehou. Prof. J.J. (Koos) Theron het as „oproeper" opgetree en dr. P.C.J. Oberholzer as sekretaris. Die destydse rektor van U.P., prof. M.C. Botha, het die verrigtinge geopen en onder andere gesê dat hy diè sligting van dic l.andbou-afdeling van die Akademic as van die allergrootste belang beskou, aangesien landbou van primêre belang is ten opsigte van die voedselvoorsiening van dic bevolking.

$\mathrm{Na}$ afhandeling van verskeie formaliteite hel prof. J.F.W. Grosskopf, Hoof van die Afdeling Ekonomie an Markte, 'n lesing oor ,Landbouwetenskap en Boeremense" gelewer. Die komitee hel gevoel dat die eerste bestuur uit vyftien lede, verteenwwoordigend vall die verskillende vertakkings van dic landbou behoort te bestaan, maar dic Fakulteitsraad het nege voorgestel. Die roterende sisteem, " aarvolgens 'n derde van die bestuur elke jaar aftree, word sleeds gehandhaaf.
Olivier en mnr. J.D. van Niekerk ontvang die toekenning van die Institution of Electrical and Electronic Engineers van die VSA vir die beste referaat van 1982 in die spesialiteitsveld van Kragstelseltegnologie.

Die afgelope 43 jaar het dus bewys gelewer dat die Afdeling Ingenieurswese ten spyte van sy relatief klein ledetal, gemeet aan die ingenieurs- en ander institute in die land, buitengewoon kon presteer deur sy lede se ywer. Die Afdeling het ook getoon dat hy hom kon aanpas by die veranderde behoeftes wat hy in die loop van die jare ervaar het. Soos die taak van die skep van 'n vaktaal gevorder het, is oorgegaan tot besinning oor landsvraagstukke waar die ingenieur 'n bydrae kan maak. Mettertyd is breër onderwerpe aangepak in simposia en by die jaarvergaderings, waartoe die oorkoepelende aard van die S.A. Akademie hom by uitstek geleen het.

Kyk ons na die toekoms is dit duidelik dat Afrikaans as vaktaal steeds ons aandag sal bly geniet, maar die groot uitdaging lê seker daarin om nog meer betrokke te raak by die uitkringende landsprobleme; die volgende logiese stap sal wees om doelbewus ons aktiwiteitsveld groter as net binne Akademieverband te sien, soos trouens alreeds gedoen is toe ons gehelp het om die GRPI te stig, om sodoende die Akademieboodskap steeds beter uit te dra. Dit sal ook die aansporing verskaf om meer jong bloed vir ons geledere te werf.
Die bestuur hel self hul ampsdraers aangewys: prof. J.J. Theron (voorsitter), dr. C.R. van der Merwe (vise-voorsitter) en dr. P.C.J. Oberholzer (sekretaris). Die enigste bestuurslid wat nie in Pretoria woonaglig was nie, was dr. S.J. du Plessis van Stellenbosch. Hierdie persone het almal diep spore in die landbouwetenskappe getrap en deur hul toewyding en harde werk die nuwe afdeling lewenskragtig gehou en uitgebou.

\section{PLAASI.IKE AKTIWITEITE}

In die vroee bestaansjare van die Afdeling was dit die gebruik om tydens die jaarvergadering, wat gewoonlik op 'n weeksaand gehou is, tyd vir twee of drie referate in te ruim. Daar is in hierdie periode telkens verwys na die wenslikheid van die uitbouing van kontak tussen alle landbounavorsers.

Daar is aanvanklik beoog om twee takke van die Afdeling te stig: een in die suide en een in die noorde. Teen hierdie agtergrond het die Tak Noord-Transvaal in 1950 tot stand gekom. Gesetel in Pretoria, en later ook bekend as die Pretoria-tak, het die bestuur hiervan gepoog om lesings oor interessante en belangrike onderwerpe in die landbou te reel. Vir baie jare is daar vier tot agt lesings per jaar oor 'n u ye reeks onderwerpe gelewer. Trouens, hierdie lak u as betreklik aktief tot vroeg in die sewentigerjare, toe kwynende belangstelling op die ontbinding daar- 
van in 1974 uitgeloop het. 'n Deel van die Afdeling se taak was waarskynlik voltooi omdat verskeie wetenskaplike vakverenigings op hierdie stadium tot stand gekom het of reeds vlot gefunksioneer het. Dit weer, was 'n direkte gevolg van die ontploffing in wetenskaplike kennis en die feit dat wetenskaplikes gedwing is om in 'n groter mate binne hul eie vakgebiede te spesialiseer.

\section{LEDETAL}

Die Afdeling Landbouwetenskappe was nog altyd een van die kleiner afdelings. Kort na sy ontstaan was daar 50 tot 60 lede, waaronder ses volle lede. Gedurende die vyftigerjare het die ledetal grootliks konstant gebly, met ongeveer tien volle lede.

Vanaf die begin van die jare sestig het die totale ledetal egter tot 90 gestyg, van wie nagenoeg 20 volle lede. Tans is die totale ledetal meer as 100 .

\section{PERSOONLIKHEDE}

\section{Die beginjare}

Die ou rekords, notules en jaarverslae lees soos 'n hoofstuk uit 'n geskiedenisboek. Die name, veral, trek die aandag.

Dr. (later prof.) P.C.J. Oberholzer, was sekretaris vanaf die begin in 1945 tot 1962. Hy het die administrasie vir baie jare self gehanteer en eers later hulp ontvang van die Akademiekantoor. Hy was ook vir 'n termyn voorsitter en het op die bestuur gedien tot 1971 .

Onder die name was daar wenners van die Havengaprys in die Landbouwetenskappe naamlik:

Wyle prof. J.J. Theron, 'n stigterslid van beide die afdeling Landbouwetenskappe en die Fakulteit Natuurwetenskap en Tegniek en 'n begeesterde akademikus. Hy was die eerste voorsitter van die Afdeling, asook voorsitter vir drie termyne daarna, en het daarna nog tien termyne op die bestuur gedien. Wyle prof. Theron tel onder die baanbrekernavorsers van ons land op die gebied van die Landbou in die algemeen en van die Grondkunde in die besonder. Sy mees betekenisvolle bydrae was egter sy aandeel in die uitbouing van die Transvaalse Streeksorganisasie gedurende sy vormingsjare, binne die Departement van Landbou-tegniese Dienste en wel tot een van die heel grootste wetenskaplike en tegniese instellings in ons land.

Wyle dr. C.R. van der Merwe, tweede voorsitter van die Afdeling vir 'n termyn van ses jaar, asook bestuurslid vir'n verdere twaalf jaar. Afgesien van sy vakwetenskaplike bydrae, het hy hom besonder beywer vir die vakterminologie.

Wyle prof. I. de V. Malherbe, akademikus van Stellenbosch en skrywer van die enigste Afrikaanse boek oor die Grondkunde, ,Grondvrugbaarheid", wat in 1933 verskyn het. Prof. Malherbe was ses jaar lank op die Afdelingsbestuur.

Dr. (later prof.) S.J. du Plessis, eerste wenner van die Havengaprys in 1949, het ononderbroke op die bestuur gedien vanaf sy ontstaan tot 1963. Prof. du Plessis het vroeg bekendheid verwerf as navorser, do- sent en outeur van 'n groot aantal vakkundige publikasies.

Wyle prof. B.J. Dippenaar, ${ }^{-H a v e n g a p r y s w e n n e r ~}$ in 1963, vroeër van Stellenbosch en later van die Universiteit van Pretoria, was 'n lojale ondersteuner van die Afdeling.

Hierdie lojàle ondersteuners van die Akademie asook baie ander, het gereeld referate gelewer by byeenkomste en in tydskrifte van die Akademie gepubliseer.

\section{Die afgelope vyf-en-twintig jaar}

Persone wat sedert die vroeë sestigerjare belangrike bydraes in Akademieverband gelewer het en aan wie die Havengaprys vir hul navorsing toegeken is, is proff. D.M. Joubert (1966), D.R. Osterhoff (1969) en B.W. Strydom (1981).

Prof. D.M. Joubert, huidige Rektor van die Universiteit van Pretoria, was by tye sekretaris, bestuurslid en voorsitter van die Afdelingsbestuur. Hy is reeds jare lid van die Fakulteitsraad asook lid van die Akademieraad. Die Havengaprys is aan prof. Joubert toegeken vir sy bydraes in die vakgebied Veekunde. Prof. D.R. Osterhoff, het die prys ontvang vir sy navorsing op bloedgroepe en biochemiese polimorfismes by diere en was verskeie termyne bestuurslid en twee termyne voorsitter. Dr. B.W. Strydom het hierdie gesogte prys ontvang vir sy navorsingsbydraes oor rhizobia. 'n Ander lid van die Akademie, prof. D.G. Haylett, hoogleraar in die Agronomie aan die Universiteit van Pretoria en baanbreker op die gebied van die Biometrie, het die Havengaprys in 1972 ontvang.

Die toekenning van die Havengaprys is egter geensins beperk tot lede van die Afdeling Landbouwetenskappe of selfs Akademielede nie. So is dit in 1975 aan prof. B.C. Jansen (Akademielid) en in 1978 aan dr. J.E. van der Plank toegeken.

\section{WOORDELYSTE EN PUBLIKASIES}

Die Afdelingsbestuur het in sy beginjare die daarstelling van 'n woordelys vir landbou en bosbou as een van sy eerste take gesien. Dr. S.J. du Plessis is genader om die leiding te neem. Prof. B.J. Dippenaar, veral, asook dr. C.R. van der Merwe, was ywerige medewerkers. Teen 1946 is daar besluit om 'n voorlopige woordelys te probeer finaliseer, en duisende terme is versamel en verwerk. In 1950 is 30000 terme as die Voorlopige Woordelys in Landbou en Bosbou deur die Akademie gepubliseer.

$\mathrm{Na} 1948$ het daar binne die Departement van Landbou, 'n landbouvaktaalkomitee onder aanvoering van dr. C.R. van der Merwe gefunksioneer, en verskeie woordelyste het verskyn. Die opdrag met betrekking tot die insameling en verwerking van vakterme in die landbou is kort na 1960 oorgedra aan die Vaktaalburo in medewerking met die Akademie en landbouwetenskaplikes.

Met die SA Tydskrif vir Landbouwetenskap wat in 1957 deur die Departement Landbou van stapel gestuur is, is daar vir die eerste keer die geleentheid vir 
publikasie in 'n tweetalige wetenskaplike tydskrif geskep. In die redaksie daarvan was Akademielede soos dr. S.J. du Plessis en prof. D.M. Joubert veral aktief. Hierdie publikasie, later in vier ,,afdelings" uitgegee, word huidiglik uitfaseer ten gunste van die nuwe nasionale tydskrifte van die Departement van Nasionale Opvoeding in samewerking met die vakverenigings.

Die Akademie steun die publikasie van handboeke in Afrikaans daadwerklik, maar min boeke op landboukundige gebied het tot dusver die lig gesien.

\section{SIMPOSIUMS}

Sedert 1967 het die Afdeling jaarliks 'n eendagsimposium oor 'n tema van aktuele belang gereël. Dit het gereeld wye belangstelling uitgelok en kan met reg beskou word as een van die min geleenthede vir interdissiplinêre kontak op hoë vlak op landboukundige gebied in Suid-Afrika. Vir 'n hele aantal jare, voor die staking van Tegnikon in 1982, is referate wat tydens die simposiums gelewer is, daarin gepubliseer. Onderwerpe soos onder andere landbounavorsing, -voorligting, -opleiding en -bemarking, mannekragbenutting en hulpverlening aan ontwikkelende state is onder die soeklig geplaas. Die sosiale sy het nie agterweë gebly nie, en sedert 1959 word daar 'n jaarlikse geselligheid gehou, meestal met 'n gasspreker, waar Akademielede mekaar beter kan leer ken.

\section{BYDRAE VAN DIE AFDELING}

Die Afdeling Landbouwetenskappe was bevoorreg om deur die jare meeste van die mees vooraanstaande landbouwetenskaplikes in Suid-Afrika as lede te kon hê. Hoewel hierdie persone baie goed in hul besondere vakgebiede gepresteer het, kon hul steeds die tyd vind om aktief in te skakel by die afdeling deur referate te lewer, in Afrikaans te publiseer en die leiding te neem in die organisasie van byeenkomste. Dit op sigself was 'n stimulus vir ander, veral die jonger wetenskaplikes, om hul deel by te dra tot die bevordering van die doelstellings van die Akademie.

\section{Afdeling Wis- en Natuurkunde}

Die eerste bestuur van die Afdeling Wis- en Natuurkunde is deur die Fakulteit aangewys en het vanaf 17 September 1943 to 31 Maart 1944 gedien. Die eerste ampsdraers was prof. dr. S.M. Naudé (voorsitter), prof. dr. D.J. van Rooy (ondervoorsitter) en dr. P.J.G. de Vos (sekretaris), almal persone wat later hulle merk in die Suid-Afrikaanse Wetenskaplike veld gemaak het. Prof. Naudé was later die President van die WNNR en dr. De Vos hoof van die Militêre Akademie te Saldanha, terwyl die goue medalje wat jaarliks aan die wenner van die Wiskunde-olimpiade toegeken word, die Dirk van Rooymedalje heet.

In die beginjare het die Afdeling veral sy aandag aan vakwoordelyste gegee. So is die vakwoordelys in Versekeringswese reeds in 1944 voltooi. Vakgebiede
Dit was ook meestal Akademielede wat in die laat vyftigerjare, die sestiger jare en die vroeë sewentigerjare die leiding geneem het by die stigting van vakverenigings, omdat daar 'n behoefte was aan byeenkomste van vakgenote. Dit was juis hierdie vakverenigings wat die opkoms na takvergaderings van die Afdeling Landbouwetenskappe laat kwyn het. Die Afdeling moet krediet kry vir die forum wat dit so baie jare gebied het om vakgenote bymekaar te bring in 'n tydperk toe ander kanale vir sodanige byeenkomste nog nie bestaan het nie. Trouens, die byeenkomste wat in die verlede deur die Afdeling gereël is, het waarskynlik as een van die belangrike prikkels gedien vir die totstandkoming van verskeie van die vak. verenigings.

Die vernaamste funksie van die Afdeling Landbou was nog altyd om landbouwetenskaplikes uit verskillende dissiplines bymekaar te bring. By sulke interdissiplinêre byeenkomste word gedagtes uitgeruil, nuwe idees geslyp en groter perspektief verkry. Dit is ook die geleentheid waar beleidvormers uiteenlopende standpunte kan aanhoor en evalueer. As sodanige kommunikasie in Afrikaans geskied en dit lei tot publikasie in hierdie taal word die doelstellings van die Akademie des te beter bevorder.

Lede van die Afdeling Landbou, en veral bestuurslede, het deur die jare 'n belangrike rol gespeel in die identifisering van verdienstelike kandidate vir Akademietoekennings soos die Havengaprys en die M.T. Steyn-medalje. Daar is min sterker aansporings tot wetenskaplike prestasie as juis die erkenning daarvan deur kollegas. In hierdie opsig het die Akademie, en in besonder die Afdeling Landbou, subtiel 'n groot bydrae gemaak tot die bevordering van navorsing in die landbouwetenskap.

Gedurende die afgelope veertig jaar is 'n stewige fondament gelê vir die bevordering van die landbouwetenskap en die Afrikaanse vaktaal. Hierdie taak hou egter nooit op nie en daar wag vele uitdagings in die toekoms. soos Wiskunde, Landmeetkunde en Natuurkunde het vroeg reeds aandag geniel, terwyl daar reeds in 1946 met die opstel van lyste Weerkunde- en Sterrekundeterme begin is. Ook is daar begin met ' $n$ lys in Wiskundige Statistiek, wat 'n baie moeilike taak was aangesien daar in die veertigerjare nòg in Nederlands, nog in Duits so 'n lys bestaan het.

By geleentheid van die eerste jaarvergadering in 1944 is ' $n$ enkele lesing gelewer, maar by die jaarvergadering wat op 26 Junie 1947 gehou is, is daar reeds elf referate aangebied.

Die voorlopige Natuurkundige Vakwoordelys het ook in 1947 verskyn en was by die Akademiesekretaris verkrygbaar teen $45 \mathrm{c}$ per eksemplaar.

Die betrokkenheid van die Afdeling by die uitgee van 'n tydskrif het in 1949 'n aanvang geneem toe 
Tegnikon sy verskyning in Julie van daardie jaar gemaak het as 'n voortsetting van die Tydskrif oor Ingenieurswese van die Ingenieursafdeling van die Akademie.

Die jaar 1949 was ook in ander opsigte vir die Afdeling 'n besondere jaar want behalwe die voorlopige Fisika-woordelys het die volgende woordelyste ook hulle verskyning gemaak:

1. Voorlopige Lys van Terme in die Wiskunde deur W.F.C. Arndt.

2. Tweetalige Weerkundige Woordelys opgestel deur die S.A. Weerburo in medewerking met die Akademie.

3. Voorlopige Lys van Terme in die Versekeringswese deur B. de Loor.

Verder het die Afdeling ook sedert 1949 oor twee takke, nl. die Pretoria-tak en die Suidelike Tak met setel te Stellenbosch, beskik.

In die vyftigerjare het die Afdeling aktief die Wetenskap en die Afrikaanse wetenskaptaal probeer bevorder deur gereeld takvergaderings en jaarvergaderings te hou waarby daar lesings en referate in Afrikaans aangebied is. Besondere aandag is ook in hierdie tydperk aan die opstel van vakwoordelyste gegee.

By geleentheid van die viering van die vyftigjarige bestaan van die Akademie in 1959 kon die Afdeling na slegs 16 jaar van bestaan op 'n periode van groei terugkyk en die voldoening smaak dat die oorspronklike doelstellings waartoe die Afdeling homself by sy stigting verplig het, met ywer en sukses nagestreef is.

Wanneer die werksaamhede van die Afdeling oor die afgelope vyf-en-twintig jaar in oënskou geneem word, blyk dit dat daar baie vermag is in die praktiese uitvoering van die doelstellings van die Akademie.

Danksy die ywer van lede van die Afdeling het 'n reeks vakwoordeboeke die lig gesien wat 'n groot stoot aan die Afrikaanse vakterminologie gegee het.

Die eerste hiervan was die Statistiekwoordeboek wat in 1961 verskyn het en wat 'n produk van die baanbrekerswerk van prof. B. de Loor was. Tans is daar 'n nuwe uitgawe in finale manuskripvorm. Dit is onder leiding van prof. H.S. Schoeman gedoen en die RGN het dit finansieel gesteun. Die WNNR se rekenaarprogram het die rangskikking van die terme en die omskakeling van die lys behartig en natuurlik geweldig baie tydbesparing meegebring.

Die Wiskundewoordebvek het in 1971 onder die redakteurskap van prof. P.J. Zietsman verskyn. Vir hierdie woordeboek is die aanvoorwerk gedoen deur prof. W.F.C. Arndt, wat in 1924 reeds 'n lys van Wiskundeterme vir eie gebruik saamgestel het. Tans word daar gewerk aan 'n hersiene uitgawe waarvoor ook deur die RGN'n toekenning gemaak is. Die werk sal hopelik in 1986 voltooi wees.

Die beskeie lys van Afrikaanse terme in Fisika wat in die jare 1935 lot 1937 deur prof. S.M. Naudé saamgestel is en wat gelei het tot dic Voorlopige Fisiese Woordelys wat in 1948 verskyn het, is opgevolg deur die Fisikawoordeboek in 1977. Tans vergader 'n aantal fisici eenmaal per jaar tydens die jaarvergadering van die Suid-Alrikaanse Instituut vir Fisika om die woordeboek deurlopend by te werk.
As ' $n$ mens in aanmerking neem hoeveel tyd deur woordeboekmaak in beslag geneem is (veral met die oog op die honderde vertalings wat geskep moes word) en dat dit gedoen is deur Afrikaanssprekende wetenskaplikes wat dit naas ' $n$ volle dagtaak aangepak het, dan is daar rede om van hierdie werke as taalmonumente te praat.

Op hierdie terrein is daar egter nog baie werk wat wag. Vakwoordeboeke in Rekenaarwetenskap, Sterrekunde en Weerkunde is hoog op die behoeftelys.

Die Afdeling het hom ook beywer vir 'n staatsondersteunde vertaaldiens wat dit vir Suid-Afrikaanse wetenskaplikes moontlik sou maak om op internasionale byeenkomste voordragte in Afrikaans te lewer.

Om die vaktaal nog sterker te vestig en om tegelyk 'n dringende diens aan die Afrikaanse studente te lewer, het die Akademie ook voogdyskap aanvaar vir Afrikaanse handboeke vir universiteitstudente. Op die terrein van hierdie Afdeling het daar met die Akademie se ondersteuning reeds drie Afrikaanse handboeke in Wiskunde verskyn waaraan personeellede van die noordelike Afrikaanse universiteite meegewerk het, naamlik Analise I, Analise 2 en Inleidende Algebra.

Lede van die Afdeling was ook betrokke by 'n Afrikaanse handboek in Statistiek en ook een in Geologie. Daar is egter nog 'n baie groot behoefte aan 'n Afrikaanse Fisikahandboek en dit is een van die Afdeling se take vir die volgende skof.

Oor die jare heen het lede van die Afdeling 'n belangrike bydrae gelewer tot die Akademietydskrifte. Veral prof. A. Strasheim het in die dae van Tegnikon en die Tydskrif vir Natuurwetenskappe, en tans as Voorsitter van die redaksiekomitee van die SuidAfrikaanse Tydskrif vir Wetenskap en Tegnologie, 'n konstruktiewe taak met toewyding behartig.

As gevolg van die opkoms van vakverenigings het die gebruik posgeval om by jaarvergaderings simposia te hou met temas wat 'n wye groep belangstellendes trek in plaas daarvan om suiwer vakgerigte referate aan te bied. Gewoonlik is daarin geslaag om coonaangewende wetenskaplikes by hierdie simposia te betrek.

Temas soos Geofisika in Suid-Afrika, Gesprekke oor Wiskunde en Materiale 2000 gee 'n beeld van die soort simposia wat aan die jaarvergaderings gekoppel is.

Die Afdeling het baie tyd bestee aan die gesproke oordrag van getalle en het probeer om 'n eenvormige oordragpatroon te skep vir gebruikers soos die weermag, burgerlugvaart, bourekenaars, ouditeurs en landmeters vir wie korrektheid so uiters belangrik is.

Die onderrig van wiskunde en fisika op sekondêre vlak was 'n verdere aktiwiteit van dic Afdeling, en dit was ook die tema by een van die jaarvergaderings.

Opsommend kan gesê word dat die Afdeling oor die afgelope 25 jaar veel gedoen het om geleenthede en fasiliteite te help skep wat dit vir die Afrikaanse naluurwelenskaplike moontlik gemaak hel om ook in sy wetenskapsbectening die Afrikanse taal te gebruik en kultuurmens te wees. 